\title{
PROFESSIONAL STATUS AND THE PERSONNEL FUNCTIONARY IN THE SADF
}

By R Adm R. Eberlein*

\begin{abstract}
Introduction
During the last year or so there has developed an increasing awareness among personnel functionaries in the SA Defence Force of a movement aimed at obtaining recognition of the professional status of the personnel function.
\end{abstract}

Several members of the SADF have already applied for and been granted such recognition by the SA Board for Personnel Practice, a nonstatutory body for the voluntary registration of personnel people who meet certain professional standards.

Why have these people voluntarily subjected themselves to an assessment of their professional worth and what do they hope to gain from registration, from professional recognition?

This paper attempts to answer those and certain other pertinent questions.

\section{Development of the personnel function in the SADF}

A history of the development of the personnel function in the SA Defence Force appeared recently (1). An unclear and tenuous but nonetheless visible line of development from the role of "administrator" to that of "personnel" functionary" can be traced here. As this historical development affects the present-day status of the personnel functionary it would be interesting to highlight certain elements.

In 1912 with the establishment of the Union Defence Force the problems of personnel were dealt with by a Staff Officer Administrative Duties in the General Staff Division.

By degrees the post developed into that of Adjudant General (AG) (in 1918) and continued developing throughout World War II. By 1946 the $A G$ and the deputy $A G$ were responsible for the administration of officers and other Ranks; military discipline; medals and decorations; as well as Chaplains Services.
By 1949, the Administrative Service Corps (ASC), forerunner to the Personnel and Ordinance Service Corps of today, had aspects such as administration, finance, supply, ammunition, transport, pay, and appointments inter alia under its control. To all intents and purposes, anything "administrative" required to support the fighting corps, was its forté.

With the dissolution of the Defence Secretariat (the SADF's channel for communication with the then Public Service Commission) in 1966, this task of negotiation on personnel matters was taken over by the AG, and his title changed to Chief of Defence Force Administration (CDFA).

By 1970 the change in emphasis from "administering personnel affairs" to being "personneloriented" in deed became visible for the first time; when the CDFA's title was changed to Director-General Personnel. Further development occurred the following year when the ASL of the SA Army was divided into four branches viz administration, supply, pay and accounting thus paving the way for a "purification" of each function.

Responsibility for the execution of the personnel function in the SADF was given to the Chief of Staff Personnel in 1974, at which time the post of CDFA disappeared. The following year saw the emergence of the Personnel Services Corps from the old ASL, formal acknowledgement of the importance of the pesonnel function to the SADF.

In the SA Air Force, SA Navy and latterly, the SA Medical Services, similar changes and developments were occurring, influenced both by their own cultures and by what was going on on high.

Essentially, in the early days a group of people was required to administer to the requirements of personnel, inter alia. They saw to the recruiting, promotion, the awarding of medals, the discharges and so on. They were in the true sense of the word "administrators" - and usually good ones at that. In modern day parlance, they 
looked after the manpower maintenance function.

The other recognised functions of personnel, being manpower planning and personnel development, were dealt with separately, and usually by General Duties personnel - todays combat personnel. To a great extent, this is still very much the case.

The fact that the General Duties Branch personnel remained the de facto heads of the emergent personnel function in the SADF may seem strange to an outsider and to many personnel functionaries in the SADF. However, from the earliest days the line officer (or General Duties officer) had the responsibility for the wellbeing of the people under his command as well as for their training and development, while the "administrator" was primarily concerned with paperwork. It was only natural and desirable that he, the line officer, should at that time control the staff function related to personnel.

The "Personnel Function" gained formal recognition in the SADF in 1974 together with the acceptance of the concept of five staff divisions ie Personnel, Operations, Intelligence, Logisitics and Finance. During the ensuing re-organisation Personnel Division emerged at CSADF Headquarters level and in each Arm of Service. These Personnel Divisions were meant to embrace the functions of Manpower Planning (and Provisioning or recruiting) Personnel Development and Manpower Maintenance, but unfortunately not all do.

Control over the staff function of personnel, with certain exceptions is still vested primarily in the General Duties Officer, with the so-called "personnel officer" playing a relatively minor role.

Why is this?

\section{Three reasons emerge:}

Firstly - tradition. The General Duties officer has always run the personnel function and has proven up to the present to have the experience and ability to do so.

Secondly - because the "Personnel officer" of the SADF is seen still to be, by and large, an "administrator" incapable of controlling the total personnel function.

Thirdly, and perhaps most importantly - the SADF has not realised that the personnel function has developed into a specialist function, which can only be handled by properly trained personnel. It has become a professional function.

To be entirely honest, in many cases the Personnel officer is just an administrator who is incapable of handling the specialist function of personnel. Is the use of the term "profession" then justifiable?

\section{The personnel function as a professional function}

Louis A. Allen (quoted by Langehoven 1981) defines a profession as follows:

"A specialised kind of work practised through the use of classified knowledge, a common vocabulary, and requiring standards of practice and a code of ethics established by a recongised body."

\section{The questions that must arise are:}

Is personnel work of a professional nature?

Is the management of human resources not complex or important enough to be regarded as a profession?

Are the applicable sciences not yet far enough advanced to serve as a basis for a profession?

Is it possible for the personnel function to be run effectively and efficiently without properly trained people?

To answer questions such as these H.P. Langenhoven (2) set up an investigation into the professionalisation of expert personnel management. The purpose of his investigation was to determine inter alia:
(a) The ratio of personnel people to total staff
(b) Qualifications of personnel people
(c) Time spent on managerial, professional, semi-professional and clerical work
(d) Areas of contribution required of personnel people
(e) Knowledge and experience required
(f) The value of professionalisation

Data was collected by questionnaires from eighty-eight organisations and 245 individual 
personnel people. The organisations included the public sector and the private sector.

Some interesting facts emerged from the study:

\section{(a) Increase in Personnel functionaries}

The number of personnel performing personnel work is increasing more rapidly than the total staff establishment. The trend indicates a growth from roughly 80000 in 1975 to 130000 in 1985 . That indicates an average annual increase of over 4000 .

(b) Personnel functionaries largely unqualified

A relatively small percentage of personnel people have relevant qualifications in personnel management. The majority $(60,9 \%)$ have no post-school training; $21,3 \%$ have a degree in behavioural science while a further $11,8 \%$ have an applicable diploma. The trend is to better qualifications and by 1985 only $56,4 \%$ would not have had post-school training.

\section{(c) Clerical work over-emphasised}

Too little time (18\% instead of $28 \%$ ) is spent on professional work. Too much time $30 \%$ instead of $20 \%$ ) is spent on clerical work and semi-professional work $(33 \%$ instead of $27 \%$ ). Managing the personnel function too, is neglected with only $19 \%$ of available time being spent on this important aspect instead of the required $25 \%$.

\section{(d)Most important personnel functions}

The five functions, in order of priority to which the personnel functionary could make the greatest contribution, were seen to be:

(i) Consultation with, advice and services to line management

(ii) Planning, implementation and evaluation of personnel systems.

(iii) Formulation of objectives and policies on personnel matters.

(iv) Research into personnel problems and recommendations for action.

(v) Administration of progammes relating to employment, training, compensation etc.

(e) Relative importance of knowledge and experience

The areas of knowledge and experience of most value to personnel functionaries, in order of importance, are: (i) Behavioural science

(ii) Economic or administrative science

(iii) Labour and administrative legislation

(iv) Anthropology and a Black language.

(v) Statistics.

From the study it therefore became evident that the nature and complexity of personnel work has developed to the stage where the Personnel function is a profession, in terms of Louis Allen's definition.

(f) $93,5 \%$ agreed that the line manager has the same need for professional assistance regarding the managing of his human resources as he has regarding the technical and financial resources, which are already recognised as professions.

\section{(g) Professional registration desirable}

$83,3 \%$ were of the opinion that the time is ripe for professionalisation and registration; that two levels of registration were desirable but that unregistered people should not be prohibited from managing personnel.

\section{Value of professional registration}

In the same study, the question was asked "what do you expect to gain from professional registration and recognition?

The anwsers to this question, linked to the earlier findings and to the brief discussion on the development of the personnel function in the SADF, indicate why some personnel functionaries in the SADF have already registered with the SA Board for Personnel Practice. The answers given indicated that the value of registration lies in:

(a) Improvement of Training. Before professional recognition is granted, a certain minimum level of education and experience is required. The minimum levels are higher than those generally held by personnel functionaries, so an improvement in training may be expected.

(b) Better services to management, employees and society. A natural output of improved training, is the ability (and hopefully) desire to render better service in ones job.

(c) Increasing professional competency.

Allied to the improvement in training is the idea that the personnel function will be carried out with a greater degree of professional competency, with its attendant advantages. 
(d) Promotion of professional conduct.

The personnel profession is dogged by complaints and comments regarding the inability of its members to function as professionals. This is allied to the concept of personnel people being primarily administrators. Meeting the standards required for registration must lead to more professional conduct.

(e) Higher Productivity.

More skilled application of the skills of the personnel functionary would contribute greatly to

(i) More productive use of manpower.

(ii) Better labour relations and

(iii) less labour problems.

These would in turn lead to better maintenance and retention of personnel.

(f) Increased status and recognition for Personnel Practitioners.

In this latter aspect lies the nub of the reason for professional recognition. By performing at a professional level, the status of the personnel functionary can be raised in the eyes both of his fellows and of the other professions, to that of a true professional.

\section{Requirements for professional registration}

The concept of professional recognition started to emerge in late 1976 early 1977. A group of concerned persons got together under the guidance of Garry Whyte and the auspices of the Institute of Personnel Management to consider the problem. This Ad Hoc committee on which the SADF was represented by Commodore R. Eberlein SA Navy started work in 1978.

The Ad Hoc committee recommended to the Council of the Institute of Personnel Management the establishment of the SA Board for Fersonnel Practice, in 1981.

The Board was appointed in Sep 1982, stil! under the Chairmanship of Mr Garry Whyte. The board consists of

(a) Seven members, who are registered Personnel Practitioners.

(b) Three members who are registered Personnel Technicians.

(c) Ten other members of whom three are from educational institutions and two from the public sector.

The Board has inter-alia as its objects: (a) The control of the standards of professional conduct of registered persons.

(b) The promotion of the standard of training.

For registration as a Personnel Practitioner the Board requires a four year academic qualification in a discipline relevant to the field of personnel practice and two years practical training and experience under the supervision of a registered Personnel Practitioner.

Registration as a Personnel Technician calls for a two-year post-matriculation qualification in a personnel discipline, plus two years practical training and experience under the supervision of a registered Personnel Practitioner.

A special dispensation clause has been included in the regulations of the Board, to permit those persons who qualify for registration on the grounds of some other admixture of education, training and experience, to register.

Since its inauguration in 1982, the composition of the Board has changed, as the terms of office of certain members drew to a close. The members of the new Board recommended that the Board apply for statutory recognition, and this process is now under way.

There has been much support for and some resistance to the concept of statutory recognition, but the indications are that the draft Personnel Bill will become law in due course.

There were in June 1986, 2812 persons registered with the SA Board for Personnel Practice, made up as follows:

$\begin{array}{lr}\text { Personnel Practitioners } & 1776 \\ \text { Personnel Technicians } & 774 \\ \text { Candidates } & 294 \\ \text { Total } & 2812\end{array}$

New registrations continue to pour in, at the rate of \pm 200 per month.

\section{Conclusion}

In this article an attempt has been made to sketch the development of the personnel function in the SADF, and to indicate why personnel functionaries play a relatively minor role in the personnel function in the SADF. Three reasons were seen to emerge ie.

- The tradition of having General Duties officers head up the personnel function. 
- The perceived role of the personnel officer as "only" an administrator.

- The SADF's failure to realise that the personnel function has developed into a professional function needing professionally trained and capable personnel.

The results of a study into the personnel function in the Republic led to the conclusions that:

- The number of personnel functionaries is increasing rapidly.

- Present personnel functionaries are largely unqualified.

- Clerical work is over-emphasised to the detriment of professional work.

- Personnel functionaries can make their greatest contribution in certain key areas.

- Certain theoretical knowledge and skills, together with practical experience are necessary for the development of professional ability.

- Professional registration is desirable.

\section{The value of professional registration was} seen to lie in the possibility of it bringing:

- improved training

- better service to management, employees and society

- increasing professional competency

- promotion of professional conduct

- higher productivity and improved labour relations, and
- increased status and recognition for personnel practitioners.

The requirement for professional recognition by the SA Board for Personnel Practice were identified and the objects of the Board indicated.

All these aspects, seen in the context of the status of the personnel functionary in the SADF today, lead one inevitably to the conclusion that:

- The personnel functionary in the SADF can expect to achieve his rightful position in the personnel hierarchy only if and when he develops the qualifications and ability necessary to function as a professional in the personnel profession.

- Registration with the SA Board for personnel Practice would indicate objectively his true standing his chosen profession and would contribute to his standing in the personnel hierarchy in the SADF.

- Registration as a Personnel Practitioner, Technician or candidate does not entitle him to enhanced status - his performance as a professional is the only guarantee of success.

* Cdre R Eberlein SD; B Mil; Dip PL and ET; Dip TE, MEd D Ed, is also a registered Personnel Practitioner.

\section{Bibliography}

1. Du Toit JJ: Die geskiedenis van die personeelfunksie in die SA Weermag sedert W01 tot 31 Jan 81: HSP Dokument: 1986.

2. Langenhoven HP: An investigation on the Professionalisation of expert personnel management: People \& Profits 1981. 